\title{
O Supremo Tribunal Federal e a aplicação dos tratados de Direitos Humanos
}

\section{The Supreme Court and application of human rights treaties}

\author{
Eduardo Biacchi Gomes* \\ Silvana Przybyzeski**
}

\section{Resumo}

O objetivo do presente artigo é abordar o processo de concretização dos tratados de direitos humanos no ordenamento jurídico brasileiro. Realizase uma análise inicial sobre a abertura do Estado brasileiro à assunção de compromissos internacionais em matéria de direitos humanos, que ocorreu, sobretudo, a partir da promulgação da Constituição da República de 1988. Em seguida, considerando o grande destaque do Poder Judiciário no cenário político atual, processo conhecido como judicialização da política, adentra-se especificamente no papel desempenhado pela jurisprudência do Supremo Tribunal Federal, na efetivação dos referidos compromissos internacionais. Nesse sentido, analisam-se as razões do julgamento do Recurso Extraordinário n. 466.343-8, que estabeleceu uma mudança de paradigma em relação ao status hierárquico ocupado pelos tratados de direitos humanos não aprovados pelo procedimento do $\S 3^{\circ}$ do art. $5^{\circ}$ da Constituição da República de 1988 , adotando, para tanto, a tese da supralegalidade. Por fim, por meio da análise jurisprudencial e doutrinária, estuda-se o comprometimento do próprio STF em relação à tese hierárquica adotada para, então, em paralelo com a teoria do constitucionalismo simbolismo, tecer algumas considerações sobre o problema da efetivação das regras de direitos humanos em países de modernidade tardia, como o Brasil.

Estágio Pós-Doutoral pela Universidade Federal do Rio de Janeiro, Doutor em Direito pela Universidade Federal do Paraná, Professor do Programa de Mestrado em Direito da UniBrasil e vice-coordenador. Editor adjunto da Revista de Direitos Fundamentais \& Democracia, Qualis B1, Professor titular de direito internacional da PUCPR e Profressor adjunto da Uninter. Curitiba - PR - Brasil. Email: ebgomes@me.com

* Acadêmica de Direito no Centro Universitário Uninter e pesquisadora do Grupo PATRIAS (Plataforma de Análises Acadêmicas e Técnicas de Direito e Relações Internacionais da América do Sul).Curitiba - PR - Brasil. Email: silvanaprz@gmail.com 
Palavras-chave: Diálogo entre jurisdições. Tratados de Direitos Humanos. Efetivação normas internacionais. Constitucionalismo.

\section{Abstract}

The purpose of this article is to discuss the process of implementation of human rights treaties in brazilian's legal system. After an initial analysis of the opening of the Brazilian state the assumption of international commitments on human rights, which occurred mainly from the enactment of the Constitution of 1988. Then, considering the highlight of the judiciary in the current political scene, a process known as legalization of politics, enters up specifically on the role played by the jurisprudence of the Supreme Court, in the realization of these commitments. In this sense, we analyze the reasons for the judgment of Extraordinary Appeal n. 466343-8, which established a paradigm shift with respect to the hierarchical status occupied by the human rights treaties not approved by the procedure of $\S 3^{\circ}$ of art. $5^{\circ}$ of the Constitution of 1988 , adopting for both the thesis of supralegalidade. Finally, by analyzing case law and doctrinal studies the commitment of the Federal Supreme Court in relation to the thesis adopted to hierarchical, then, in parallel with the theory of constitutionalism symbolism, some considerations with regard to the problem of realization rules human rights in countries of late modernity, such as Brazil.

Keywords: Human rights treaties. Late Modernity. Symbolism.

\section{Introdução}

O Estado brasileiro é considerado pela doutrina como sendo um país de modernidade $\operatorname{tardia}^{1}$ (STRECK, 2011, p. 35-36), uma vez que, diante de grandes períodos de instabilidade política e opressão vividos, em especial nos anos da Ditadura Militar, somente se estabeleceu como

\footnotetext{
O Brasil ingressou tardiamente nesse "novo mundo constitucional", fator que, aliás, é similar à realidade europeia, que, antes da segunda metade do séc. XX não conhecia o conceito de constituiçãonormativa, já consideravelmente decantada no ambiente constitucional estadunidense. Portanto, falar de neoconstitucionalismo implicava ir além de um constitucionalismo de feições liberais - que, no Brasil, sempre foi um simulacro em anos intercalados por regimes autoritários - em direção a um constitucionalismo compromissório, de feições dirigentes, que possibilitasse, em todos os níveis, a efetivação de um regime democrático em terrae brasilis.
} 
um Estado democrático, garantidor dos direitos fundamentais e aberto aos princípios internacionais de direitos humanos tardiamente, com a promulgação da Constituição da República Federativa de 1988.

Nesse novo Estado Democrático de Direito, ocorre um certo deslocamento do centro de decisões do Legislativo e do Executivo para o plano da justiça constitucional, "onde inércias destes Poderes passam a ser, em determinadas circunstâncias, supridas pelo Judiciário, mediante a utilização dos mecanismos jurídicos previstos na própria Constituição". (STRECK, 2011, p. 63).

Um exemplo da atuação compensatória do Poder Judiciário brasileiro com relação aos direitos humanos se deu com relação à atribuição do atual status hierárquico normativo dos tratados internacionais referente ao tema, o que ocorreu em 2008 com o julgamento, pelo Supremo Tribunal Federal, do Recurso Extraordinário n. 466.343-8, que estabeleceu, ainda que de forma não unânime, a tese da supralegalidade aos tratados não recepcionados nos termos da regra do $\S 3^{\circ}$, do art. $5^{\circ}$ da CRFB/88.

Neste contexto, o objetivo principal do presente artigo é analisar, a partir de um paralelo com os conceitos de modernidade tardia, trabalhado por Lenio Luiz Streck (2011), e do constitucionalismo simbólico descrito por Marcelo Neves (2011), a forma como se deu o processo de abertura do Estado brasileiro aos compromissos internacionais de direitos humanos e como estes integram a realidade social e as políticas do Poder Público.

Sabendo que o Direito é um saber prático e que qualquer teoria jurídica deve buscar, sobretudo, condições para a real concretização de direitos (STRECK, 2011, p. 378), faz-se, por fim, um estudo da jurisprudência do STF após 2008 a fim de averiguar o comprometimento deste com a tese então adotada para a hierarquia dos tratados de direitos humanos, de modo a criar reflexões sobre a sua efetivação.

A importância do estudo revela-se no fato de que a incorporação da normativa internacional de proteção no direito interno dos Estados constitui alta prioridade nos dias atuais e do aperfeiçoamento de medidas 
nacionais de implementação destas depende, em grande parte, o futuro da própria proteção internacional dos direitos humanos.

\section{A Constituição da República Federativa do Brasil de 1988 e o Processo de Internacionalização dos Tratados Internacionais de Direitos Humanos}

Apesar da íntima relação existente entre "direitos humanos" e "direitos fundamentais", uma vez que ambos têm como titular a pessoa humana e buscam positivar os direitos naturais desta (SARLET, 2001, p. 33 e 35), é necessário estabelecer a diferença terminológica entre as duas expressões que corriqueiramente são utilizadas como sinônimas.

Conforme lição de Ingo W. Sarlet (2001, p. 33), direitos fundamentais são os direitos da pessoa humana positivados no âmbito do Direito Constitucional de determinado Estado, enquanto que os direitos humanos referem-se à positivação no âmbito do Direito Internacional Público, por meio dos tratados e convenções internacionais. (MAZZUOLI, 2007, p. 804-805).

Flávia Piovesan (2011, p. 67-70) e Antônio Augusto Cançado Trindade (2003, p. 401-402) defendem a fusão e a interação entre o Direito Constitucional (direito interno) e o Direito Internacional dos Direitos Humanos, que juntos formariam um todo harmônico que objetiva resguardar um mesmo valor: o valor da primazia da pessoa humana, o que resultaria num ordenamento jurídico de proteção denominado Direito Constitucional Internacional, de modo a se produzir um modelo que mais eficazmente possa proteger os direitos da pessoa humana².

De qualquer forma, a positivação de direitos fundamentais em textos constitucionais teve início com as revoluções liberais ocorridas

\footnotetext{
Antônio Augusto Cançado Trindade (2003) defende ainda que já não se justifica que o direito internacional e o direito constitucional continuem sendo abordados de forma estanque ou compartimentalizada, como foram no passado. Já não pode haver dúvida de que as grandes transformações internas dos Estados repercutem no plano internacional e a nova realidade formada provoca mudanças na evolução interna e no ordenamento constitucional dos Estados afetados.
} 
no século XVIII na Inglaterra (Revolução Inglesa de 1688), nos EUA (Declaração de Independência de 1776) e na França (Revolução Francesa de 1789), acontecimentos que são vistos como marco do constitucionalismo moderno. (COMPARATO, 2001, p. 47-50).

Naquele período as ideias "Constituição" e "direitos fundamentais" passaram a ser consideradas paralelas, ambas compreendidas como limites normativos ao poder estatal (STERN, 1988, p. 181 apud SARLET, 2001, p. 61), e "representaram a emancipação histórica do indivíduo perante os grupos sociais aos quais ele sempre se submeteu". (COMPARATO, 2001, p. 50).

Para além da função originária de defesa da liberdade individual, os direitos fundamentais elevados a nível constitucional se tornaram elementos da ordem jurídica objetiva, integrando um sistema axiológico que atua como fundamento material de todo o ordenamento jurídico. (SARLET, 2001, p. 64).

A concepção de Constituição apenas como mero norte interpretativo começou a ser alterada com a afirmação dos direitos econômicos, sociais e culturais ou, como são comumente chamados, direitos fundamentais de segunda dimensão, "resultado dos movimentos reivindicatórios do decorrer do século XIX, como resposta ao impacto da industrialização e dos graves problemas sociais e econômicos que a acompanharam". (SARLET, 2001, p. 51).

Ao contrário dos direitos de primeira dimensão, que visavam evitar a intervenção do Estado na liberdade individual, os direitos sociais exigiam um Estado atuante e, por consequência, uma Constituição que não tivesse apenas força declaratória (CANOTILHO, 2003, p. 1.150), mas também força normativa ${ }^{3}$, vinculando sempre, positiva ou negativamente, os Poderes Públicos (CLĖVE, 2000, p. 28).

3 O conceito de força normativa da constituição foi melhor desenvolvido por Konrad Hesse em 1959, (1991, p. 18-19) para quem, embora estejam implícitos na constituição os fatores reais de poder, ela (a Constituição) também possui uma força própria, motivadora e ordenadora da vida do Estado. "Embora a Constituição não possa, por si só, realizar nada, ela pode impor tarefas". 
Conforme anota Ingo W. Sarlet (2001, p. 51), "foi no século XX, contudo, que estes novos direitos acabaram sendo consagrados em um significativo número de textos constitucionais e serem objetos de pactos internacionais".

Isso foi decorrência, em especial, da tomada de consciência, pela sociedade, das grandes atrocidades e violações cometidas pelos próprios Estados em nome da legalidade no período das duas Grandes Guerras Mundiais (BARROSO; BARCELLOS, 2003).

Percebeu-se que o positivismo jurídico alheio a qualquer elemento axiológico e valores éticos tinha se mostrado desastroso (BARROSO; BARCELLOS, 2003) $)^{5}$ e fez-se necessária a reformulação de alguns conceitos então vigentes que fundamentavam a legitimação do poder, de modo a promover o retorno de alguns valores do naturalismo como o reconhecimento da normatividade dos princípios, especialmente 0 princípio da dignidade humana e a reaproximação entre ética e Direito. (PIOVESAN, 2011, p. 81-82) 6 .

Conforme já referido, neste cenário de pós-guerras, também institucionaliza-se definitivamente ${ }^{7}$ o Direito Internacional dos Direitos

4 Antônio Augusto Cançado Trindade (2007.p.216) aponta, ainda, que "os países emergidos da descolonização em muito contribuíram para esta nova visão global, premidos pelos problemas comuns da pobreza extrema, das enfermidades, das condições desumanas de vida, do apartheid, do racismo e discriminação racial".

5 "Ao fim da Segunda Guerra Mundial, a ideia de um ordenamento jurídico indiferente a valores éticos e da lei como uma estrutura meramente formal, uma embalagem para qualquer produto, já não tinha mais aceitação no pensamento esclarecido".

6 Para Flávia Piovesan isso representou um reencontro com o pensamento kantiano, com as ideias de moralidade, dignidade, direito cosmopolita e paz perpétua. Cita, ainda, que para Immanuel Kant (In: Fundamental Principles of the Metaphysics of Morals, 2001), "as pessoas devem existir como um fim em si mesmo e jamais como um meio, a ser arbitrariamente usado para este ou aquele propósito".

7 "Definitivamente" porque, conforme anota Fábio Konder Comparato (2001), a partir da segunda metade do séc. XIX, já iniciava-se o processo de internacionalização dos direitos humanos no campo do direito humanitário, com a Convenção de Genebra (1864) estabelecendo as leis e costumes da guerra, visando minorar o sofrimento dos sujeitos envolvidos, e que originou a fundação da Comissão Internacional da Cruz Vermelha em 1880; na campo da luta contra a escravidão com o Ato Geral da Conferência de Bruxelas (1890), que estabeleceu as primeiras regras interestatais de repressão ao tráfico de escravos africanos; também no campo da proteção do trabalhador, com a criação da OIT (Organização Internacional do Trabalho), em 1919. 
Humanos que eclode como instrumento contra a arbitrariedade estatal por meio do estabelecimento, em âmbito internacional, de um mínimo a ser respeitado por todos os Estados.

Esse movimento de maior abertura aos princípios e regras jurídicas internacionais de direitos humanos e de cooperação entre os Estados, de modo a afastar, conforme coloca José Joaquim Gomes Canotilho (2003, p. 232), a arrogância do "orgulhosamente sós"8 e elevar valores como a dignidade da pessoa humana ao centro dos fundamentos de existência do Estado, exerceu grande influência nas Constituições que se sucederam em vários países (TRINDADE, 2003, p. 404-410)

No Estado brasileiro a mudança efetiva com relação à proteção dos direitos da pessoa humana ocorreu somente após a promulgação da Constituição de 1988, que deu início à consolidação de um Estado Democrático de Direito e atribuiu aos direitos fundamentais e à dignidade da pessoa humana um papel central (CANOTILHO, 2003, p. 269) ${ }^{9}$ e normativo.

Neste sentido, estabeleceu a Constituição que dentre os princípios que hão de reger as relações internacionais encontra-se o princípio da prevalência dos direitos humanos (art. $4^{\circ}$, II) e reconheceu os direitos e garantias decorrentes de tratados internacionais de que a República

8 Expressão utilizada por José Joaquim Gomes Canotilho (2003, p. 234) ao referir-se à abertura da Constituição de Portugal aos preceitos do direito internacional. "Hoje, os limites impostos ao Estado advém também, em medida crescente, de princípios e regras jurídicas internacionais. Estes princípios e regras são, em grande número, recebidos ou incorporados no direito interno fazendo parte 'of the Law of the land' (CRP, artigo $8^{\circ}-1$ e 2). Nenhum Estado pode permanecer 'aut', isto é, fora da comunidade internacional. Por isso, ele deve submeter-se às normas de direito internacional quer nas relações internacionais quer no próprio actuar interno. A doutrina mais recente acentua mesmo a amizade e a abertura ao direito internacional como uma das dimensões caracterizadoras do Estado de direito".

9 "Essa abertura internacional pressupõe a abertura da constituição que deixa de ter a pretensão de fornecer um esquema regulativo exclusivo e totalizante assente em um poder estatal soberano para aceitar os quadros ordenadores da comunidade internacional. A abertura internacional significa, em segundo lugar, a afirmação do direito internacional como direito do próprio país e o reconhecimento de alguns dos seus princípios ou regras como medida de justiça, vinculativa da própria ordem jurídica interna". 
Federativa do Brasil seja parte $\left(\S 2^{\circ}\right.$ do art. $\left.5^{\circ}\right)$, o que caracteriza a abertura material da Constituição aos direitos humanos ${ }^{10-11}$.

Dessa forma, no Brasil, a positivação dos direitos fundamentais na Constituição e a abertura do Estado à assunção de compromissos internacionais de direitos humanos se deram ao mesmo tempo ${ }^{12}$, como fruto da política de uma sociedade carente de direitos e inquieta por sair de um regime autoritário ${ }^{13}$, razão pela qual o estudo da efetivação de ambos os institutos caminham juntos e enfrentam os mesmos problemas relativos à sua implementação.

No que diz respeito aos tratados de direitos humanos, a Constituição da República de 1988 não estabeleceu, a princípio, nenhuma diferença expressa de tratamento hierárquico entre os tratados que versam sobre temas de direitos humanos e os que tratam de outros temas. ${ }^{14}$

Tal situação persistiu até a promulgação da Emenda Constitucional n. 45 , de dezembro de 2004 , que ao inserir o $\S 3^{\circ}$ no art. $5^{\circ}$ da Constituição dispôs que os tratados e convenções internacionais de direitos humanos que fossem aprovados em cada Casa do Congresso Nacional, em dois turnos, por três quintos dos votos dos respectivos membros, seriam equivalentes às emendas constitucionais.

10 Nesse sentido, conferir Miranda (1996. t. IV, p. 153), - o autor denomina esta abertura da constituição de "cláusula aberta" ou de "princípio da não tipicidade dos direitos fundamentais"; e Canotilho (2003, p. 380), que, por sua vez, denomina de "norma com fattispecie aberta".

11 Nas palavras de Antônio Augusto Cançado Trindade (1991, p. 631): "[...] a nova Constituição Brasileira vem, assim, fortalecer a tendência de Constituições recentes de reconhecer a relevância da proteção internacional dos direitos humanos e dispensar atenção e tratamento especial à matéria."

12 No Estado brasileiro também não é perceptível as chamadas dimensões ou gerações de direitos, pois ao mesmo tempo em que foi assegurado direitos de liberdade, foram assegurados os direitos sociais e até os direitos de terceira dimensão como os relativos à proteção do meio ambiente.

13 Sobre o processo de transição do Regime Militar para o Regime Democrático no Brasil, conferir Coelho (2012).

14 Salvo para os que defendem que pela redação do $\S 2^{\circ}$ do art. $5^{\circ}$, (os direitos e garantias expressos na Constituição não excluem outros decorrentes do regime e dos princípios por ela adotados, ou dos tratados internacionais em que a República Federativa do Brasil seja parte), a Constituição de 1988 previu uma cláusula aberta de recepção, com hierarquia constitucional, dos tratados internacionais de direitos humanos de que o Brasil seja parte. Neste sentido, conferir Piovesan (2011, p.103-110); Mazzuoli (2007, p. 819-821); Trindade (1991, p. 407-408). 
A referida reforma recebeu muitas críticas pelo fato de que o $\S 2^{\circ}$ do art. $5^{\circ}$ do texto constitucional já disciplinava a matéria, ${ }^{15}$ conferindo aplicabilidade imediata e status hierárquico constitucional aos tratados internacionais de direitos humanos em razão da teoria do bloco de constitucionalidade e da constituição material ${ }^{16}$, crítica da qual partilhamos.

Entretanto, longe de solucionar a controvérsia existente sobre a posição hierárquica ocupada pelos tratados de direitos humanos, a referida emenda trouxe mais problemas, pois surgiu a questão emblemática de saber qual era o status ocupado pelos tratados internacionais, também referentes a direitos humanos, mas que não haviam sido incorporados nos termos da nova regra, principalmente os ratificados antes da Emenda n. 45/2004.

Desta forma, verifica-se que, apesar do grande avanço para a proteção dos direitos humanos trazido pelo constituinte de 1988 e pela Emenda n. 45/2004, este parece ter pecado ao se omitir sobre a forma de regular as tensões que inevitavelmente surgiriam entre o direito interno e o direito internacional no campo da proteção dos direitos humanos, tarefa árdua que parece ter sido deixada aos intérpretes da Constituição, especificamente ao Supremo Tribunal Federal.

Essa atribuição da função de intérprete do texto constitucional e de garantidor da efetividade dos direitos previstos neste ao Poder Judiciário é uma característica marcante da concepção normativa da

15 Valério de Oliveira Mazzuoli (2007, p.820) afirma que "a alteração do texto constitucional, que pretendeu pôr termo ao debate quanto ao status dos tratados internacionais de direitos humanos no direito brasileiro, é um exemplo claro da falta de compreensão e de interesse (e, sobretudo, de boa vontade) do nosso legislador relativamente às conquistas já alcançadas pelo nosso Direito Internacional dos Direitos Humanos nessa seara".

16 Salvo para os que defendem que pela redação do $\S 2^{\circ}$ do art. $5^{\circ}$ ("os direitos e garantias expressos na Constituição não excluem outros decorrentes do regime e dos princípios por ela adotados, ou dos tratados internacionais em que a República Federativa do Brasil seja parte"), a Constituição de 1988 previu uma cláusula aberta de recepção, com hierarquia constitucional, dos tratados internacionais de direitos humanos de que o Brasil seja parte. 
Constituição, principalmente nos países recém-democratizados como o Brasil e os demais países da América Latina, desempenhando papel fundamental na efetivação dos direitos humanos e no cumprimento dos compromissos assumidos internacionalmente.

Em razão disso, o próximo tópico do presente artigo ocupar-se-á de melhor abordar este tema, conhecido como justicialização da política para, posteriormente, poder ser feita a análise do processo de efetivação dos tratados internacionais de direitos humanos no ordenamento jurídico brasileiro.

\section{O papel atribuído ao Poder Judiciário para a efetivação dos Direitos Humanos}

A exigência de efetivação do texto constitucional, de modo a "resgatar as promessas incumpridas da modernidade" (STRECK, 2011, p. 24), "fez com que fosse redefinida a clássica relação entre os Poderes do Estado, passando o Judiciário (ou os tribunais constitucionais) a fazer parte da arena política", processo conhecido como judicialização da política.

Nas palavras de Luiz Roberto Barroso (2013, p. 02),

Judicialização significa que questões relevantes do ponto de vista político, social ou moral estão sendo decididas, em caráter final, pelo Poder Judiciário. Trata-se, como intuitivo, de uma transferência de poder para as instituições judiciais, em detrimento das instâncias políticas tradicionais, que são o Legislativo e o Executivo.

Isso é decorrência, dentre outros fatores, de "uma certa desilusão com a política majoritária, em razão da crise de representatividade e de funcionalidade dos parlamentos em geral". (BARROSO, 2013, p. 02-03).

A sociedade não podia mais contentar-se apenas com a boa vontade dos Poderes Executivo e Legislativo para ver seus direitos efetivados e, assim, se reconheceu a importância de um Judiciário 
forte e independente ${ }^{17}$ o que pode ser sentido na Constituição brasileira de 1988 com a implementação de mecanismos de supressão das omissões, por meio das ações como a do mandado de injunção e da ação de inconstitucionalidade por omissão, conferindo, dessa forma, maior poder ao Judiciário para compensar a não atuação dos demais poderes.

Neste cenário passa-se, então, a discutir o papel desempenhado pelo Poder Judiciário no contexto do Estado Democrático de Direito o que, conforme afirma Lenio Luiz Streck (2011, p. 52), "trata-se do elemento decisivo para o enfrentamento dos dilemas atuais da hermenêutica jurídica", que dentre outros temas aborda a questão da efetividade dos direitos fundamentais e dos direitos humanos nas sociedades de modernidade periférica. ${ }^{18}$

Em âmbito doutrinário, a questão da função do Poder Judiciário no Estado Democrático de Direito é tratada sobre dois aportes teóricos, denominados procedimentalismo e substancialismo.

O procedimentalismo tem como maiores expoentes Habermas e Luhmann (LUDWIG, 2005, p. 145), que apesar de desenvolverem suas teses sobre paradigmas diferentes, "têm visto a Constituição como uma garantia para que o jogo político ocorra dentro da lei”, devendo, o Judiciário, apenas garantir isto (HOMMERDING, 2006. 26).

17 Luiz Roberto Barroso (2013) atribui como causa da jurisdicialização da política, ainda, o fato de que os atores políticos, muitas vezes, preferem que o Judiciário seja a instância decisória de certas questões polêmicas, em relação às quais exista desacordo moral razoável na sociedade. Com isso, evitam o próprio desgaste na deliberação de temas decisivos, tais como uniões homoafetivas, interrupção de gestação ou demarcação de terras indígenas. No Brasil, o fenômeno assumiu proporção ainda maior, em razão da constitucionalização abrangente e analítica e do sistema de controle de constitucionalidade vigente entre nós, em que é amplo o acesso ao Supremo Tribunal Federal por via de ações diretas.

18 Expressão utilizada por Marcelo Neves (2011, p. 52) para se referir aos países considerados de terceiro mundo, que justifica o seu emprego em razão de "o advento da sociedade moderna estar intimamente vinculado a uma profunda desigualdade econômica no desenvolvimento interregional, trazendo consequências significativas na reprodução de todos os sistemas sociais, principalmente no jurídico e no político, estatalmente organizados". 
Para Habermas (1997, p. 326), os Tribunais Constitucionais devem buscar uma interpretação procedimental da Constituição ${ }^{19}$, limitando-se, apenas, a proteger um processo de criação democrática do Direito, caso contrário, assumiriam uma posição autoritária, como se fosse legislador, atropelando a função originária dos cidadãos.

Já para Luhmann, que trabalha com a teoria sistêmica/autopoiética, "o Direito é um sistema que tem sua própria linguagem e que se auto reproduz, independentemente do que se passa no sistema político ou nos demais sistemas" sendo que, nas sociedades complexas, a natureza das decisões deve ceder lugar aos procedimentos, que generalizam o reconhecimento das decisões, tornando os procedimentos a garantia de decisões que terão aceitabilidade (STRECK, 2011, p. 14).

A teoria substancialista, por sua vez, defendida dentre outros por Jorge Miranda (1996, p. 67-68), Paulo Bonavides (1993, p. 9-10), Lenio Luiz Streck (2011, p. 55-59) e, em certa medida, Ronald Dworkin (2001, p. 31-32), ${ }^{20}$ aposta na jurisdição constitucional como instrumento de defesa dos direitos fundamentais (e não apenas da defesa do procedimento democrático, como os procedimentalistas), ou seja, atribui um papel concretizador de direitos ao Poder Judiciário.

A Constituição do Brasil de 1988 trouxe uma mudança fundamental no Estado brasileiro com a "constitucionalização" de inúmeros direitos sociais e coletivos e a abertura para a internacionalização de tratados internacionais de direitos humanos. Assim, conforme destaca Adalberto Hommerding (2006, p. 34),

[...] passa-se de uma ordem em que o acesso ao Judiciário se restringia a pedir proteção para o que já se tinha, para

19 "O tribunal constitucional precisa examinar os conteúdos de normas controvertidas especialmente no contexto dos pressupostos comunicativos e condições procedimentais do processo de legislação democrático".

20 Para Dworkin (2001, p.31) "[...] numa democracia o poder está nas mãos do povo, mas é por demais evidente que nenhuma democracia proporciona a igualdade genuína de poder político. Muitos cidadãos, por um motivo ou outro, são inteiramente destituídos de privilégios. [...] Se os tribunais tomam a proteção de direitos individuais como sua responsabilidade especial, então as minorias ganharão em poder político, na medida em que o acesso aos tribunais é efetivamente possível e na medida em que as decisões dos tribunais são efetivamente fundamentadas". 
uma 'ordem promocional', em que se pode recorrer ao Judiciário para obter o auxílio para o que ainda não se tem, mas que se deseja por força das promessas constitucionais.

No entanto, para o próprio Lenio Luiz Streck (2011, p. 58) (substancialista), no plano do agir cotidiano dos juristas no Brasil, nenhuma das duas teses é perceptível, isso porque,

[...] o Judiciário preparado para lidar com conflitos interindividuais, próprios de um modelo liberal-individualista, não está preparado para o enfrentamento dos problemas decorrentes da transindividualidade, própria do (novo) modelo advindo do Estado Democrático de Direito previsto na Constituição promulgada em 1988; por outro lado, em face da democracia delegativa que vivemos, [...] no interior do qual o Legislativo é atropelado pelo decretismo do Poder Executivo, também não temos garantido o acesso à produção democrática das leis e dos procedimentos que apontam para o exercício dos direitos previstos na Constituição.

Diante disso e considerando que atualmente vivencia-se uma tensão entre os Poderes em torno da delimitação de suas competências e possibilidades de interferências ${ }^{21}$, a compreensão das teorias procedimentalista e substancialista se mostra muito importante para proporcionar uma reflexão e impulsionar novos horizontes teóricos sobre a lógica da divisão dos Poderes.

A divisão dos poderes recebe uma nova leitura a partir dessas teorias, a primeira apostando no Legislativo, como representante de uma sociedade democraticamente organizada e a segunda que desloca para

21 A tensão parece estar mais presente no âmbito federal entre o Poder Legislativo, representado pelo Congresso Nacional e o Judiciário, pelo Supremo Tribunal Federal. Encontra-se em trâmite, inclusive, uma Proposta de Emenda Constitucional (PEC n. 33), que visa justamente combater o ativismo judicial exacerbado aumentando os poderes controladores do Congresso Nacional sobre as decisões do Supremo no âmbito do controle de constitucionalidade, o que tem acirrado ainda mais o debate. Disponível em: <http://www.camara.gov.br/proposicoesWeb/prop_mostrarin tegra?codteor=876817\&filename=PEC+33/2011>. 
o Judiciário a função mandatária de realização dos valores e princípios relativos aos direitos da pessoa humana.

Por isso, no próximo tópico aborda-se um caso que pode ser tomado como exemplo da atuação mais ativista por parte do Supremo Tribunal Federal em matéria de direitos humanos, destacando algumas das razões adotadas no julgamento para a adoção da postura "concretizadora de direitos".

\section{O Supremo Tribunal Federal e os Direitos Humanos: julgamento do recurso extraordinário $466.343-8^{22} e$ a tese da supralegalidade}

O Recurso Extraordinário n. 466.343 foi interposto para discutir a (in)compatibilidade do art. $4^{\circ}$ do Decreto-Lei n. 911 , de $1^{\circ}$ de outubro de $1969^{23}$ - que concede ao credor fiduciário ação de depósito fundada no contrato de alienação fiduciária em garantia quando não encontre o bem ou não se ache este na posse do devedor fiduciante - com a norma do art. 153, § 17, da Emenda Constitucional n. 1, de 1969, que vedava a prisão civil por dívida, multa ou custas, salvo o caso de depositário infiel ou do responsável pelo inadimplemento de obrigação alimentar, na forma da lei.

22 “EMENTA: PRISÃO CIVIL. Depósito. Depositário infiel. Alienação fiduciária. Decretação da medida coercitiva. Inadmissibilidade absoluta. Insubsistência da previsão constitucional e das normas subalternas. Interpretação do art. $5^{\circ}$, inc. LXVII e $\S \S 1^{\circ}, 2^{\circ}$ e $3^{\circ}$, da $C F$, à luz do art. $7^{\circ}, \S$ $7^{\circ}$, da Convenção Americana de Direitos Humanos (Pacto de San José da Costa Rica). Recurso improvido. Julgamento conjunto do RE n. 349.703 e dos HCs n. 87.585 e n. 92.566. É ilícita a prisão civil de depositário infiel, qualquer que seja a modalidade do depósito". BRASIL. Supremo Tribunal Federal. Recurso Extraordinário n. 466.343-8, Relator(a): Min. CEZAR PELUSO, Tribunal Pleno, julgado em 03/12/2008. Disponível em: <www.stf.jus.br>. Acesso em: 20 jan. 2013.

23 "Art. $4^{\circ}$. Se o bem alienado fiduciariamente não for encontrado ou não se achar na posse do devedor, o credor poderá requerer a conversão do pedido de busca e apreensão, nos mesmos autos, em ação de depósito, na forma prevista no Capítulo II, do Título I, do Livro IV, do Código de Processo Civil." (Redação dada pela Lei n. 6.071, de 1974). BRASIL. Decreto-Lei n. 911, de $1^{\circ}$ de outubro de 1969. Disponível em: <http://www.planalto.gov.br/ccivil_03/decreto-lei/1965-1988/ Del0911.htm>. Acesso em: 12 abr. 2013. 
O relator do processo, Ministro Cézar Peluso, votou pelo improvimento do pedido com fundamento em que o contrato de alienação fiduciária não mantém com o depósito convencional nenhuma identidade ou afinidade jurídica e que aplicar a prisão civil neste caso, em condição análoga à do depositário, seria operação técnico-normativa inaceitável e que entra em contraste aberto com a norma constitucional exceptiva, que por seus caracteres, não tolera interpretação expansiva capaz de aniquilar o direito mesmo que se ordena a proteger sob o comando excepcionado. ${ }^{24}$

O Revisor do processo, Ministro Gilmar Mendes, também negou provimento ao recurso, mas utilizou-se de outro argumento, que foi seguido pela maioria dos demais ministros que compunham o plenário na ocasião e que alterou significativamente o tratamento dispensado aos tratados internacionais de direitos humanos no ordenamento jurídico brasileiro, dando nova interpretação ao texto constitucional.

Para o Ministro Gilmar Mendes, conforme dispõe o art. $7^{\circ}$ (n. 7) da Convenção Americana sobre Direitos Humanos - Pacto de San José da Costa Rica, de 1969, de que faz parte a República Federativa do Brasil ${ }^{25}$ - salvo por inadimplemento de obrigação alimentar, ninguém deve ser detido por dívidas.

A questão em voga, então, foi analisar o aparente conflito de normas sobre a possibilidade ou não de prisão civil do depositário infiel, já que o texto constitucional, além do inadimplemento dos alimentos prevê esta modalidade de prisão no art. $5^{\circ}$, inc. LXVII, conflito que, para o Ministro Gilmar Mendes, deveria ser resolvido com base no critério hierárquico das normas, conforme a pirâmide normativa de Hans Kelsen.

24 Para maiores informações, consultar: STF. Recurso Extraordinário n. 466.343-8.

25 Este tratado teve sua implementação no ordenamento jurídico brasileiro com a promulgação do Decreto n. 678, em 06 de novembro de 1992. Disponível em: <http://www.planalto.gov.br>. Acesso em: 23 jan. 2013. 
Inicialmente o Ministro fez uma vasta exposição sobre cada uma das possíveis teorias sobre a hierarquia normativa dos tratados internacionais de direitos humanos, ${ }^{26}$ quais sejam:

(1) a vertente que reconhece a natureza supraconstitucional dos tratados e convenções em matéria de direitos humanos, onde, em razão da relevância do tema, essas regras deveriam ser inclusive superiores ao texto constitucional dos Estados nacionais;

(2) o posicionamento que atribui caráter constitucional a esses diplomas internacionais, onde o possível conflito entre regra de direitos humanos e regra constitucional deveria ser resolvido pela técnica da ponderação e do melhor interesse da vítima;

(3) a tese que reconhece o status de lei ordinária a estas regras, que era adotada pelo STF até 2008; e, por fim,

(4) a tese do caráter supralegal destes documentos, que prevê que as regras de direitos humanos provenientes de tratados internacionais estariam acima de toda a legislação infraconstitucional, porém, abaixo da Constituição.

Após, amparado pela doutrina de Peter Haberle (MENDES; VALE, 2013, p. 10-11), o Revisor propôs uma mudança na jurisprudência em vigor até então (procedimentalista) do STF que atribuía status de lei ordinária aos tratados de direitos humanos justificando que:

$\mathrm{Na}$ atualidade se vive em um 'Estado Constitucional Cooperativo', que não é mais um Estado Constitucional voltado apenas para si mesmo, mas sim um Estado que se disponibiliza como referência para os outros Estados Constitucionais membros de uma comunidade internacional e no qual ganha relevo o papel dos direitos humanos e fundamentais. (Rec. Ext. 466.343-8)

Neste contexto, afirmou que equiparar as regras de direitos humanos internacionais à legislação ordinária seria subestimar o seu

26 Para maiores informações, consultar: STF. Recurso Extraordinário n. 466.343-8. 
valor especial no contexto do sistema de proteção dos direitos da pessoa humana.

Justificou, ainda, que na Constituição da República de 1988 existem disposições que remetem o intérprete para realidades normativas relativamente diferenciadas em face da concepção tradicional do direito internacional público e que sinalizam para uma maior abertura constitucional para o direito internacional revelando uma tendência contemporânea do constitucionalismo mundial de prestigiar as normas internacionais destinadas à proteção do ser humano.

A tese do status supralegal dos tratados e convenções internacionais defende o argumento de que os tratados sobre direitos humanos seriam infraconstitucionais, porém, diante de seu caráter especial em relação aos demais atos normativos internacionais, também seriam dotados de um atributo de supralegalidade, ou seja, apesar de terem um lugar especial reservado no ordenamento jurídico os tratados sobre direitos humanos não poderiam afrontar a supremacia da Constituição e estariam sujeitos ao controle de constitucionalidade.

Diante desses argumentos o Ministro Gilmar Mendes considerou ser mais consistente utilizar a tese da supralegalidade, a qual, no caso in concreto ampararia a interpretação de que com a supremacia da Constituição sobre os atos normativos internacionais a previsão constitucional da prisão civil do depositário infiel (art. $5^{\circ}$, inc. LXVII) não teria sido revogada pelo ato de adesão do Brasil ao Pacto Internacional dos Direitos Civis e Políticos (art. 11) e à Convenção Americana sobre Direitos Humanos - Pacto de San José da Costa Rica (art. $7^{\circ}$, item 7) -, mas que a previsão infraconstitucional (art. $4^{\circ}$ do Decreto-Lei n. 911/1969) deixou de ter aplicabilidade diante do efeito paralisante desses tratados em relação a esta.

O referido entendimento foi acolhido pela maioria dos demais Ministros que compunham o Plenário e apesar de não ser dominante no STF é o que, em tese, ainda estaria em vigor e, de certa forma, determina o status normativo ocupado pelas regras provenientes de tratados internacionais de direitos humanos no ordenamento jurídico brasileiro. 
Entretanto, é importante mencionar, ainda, o voto do Ministro Celso de Mello, que amparado pela doutrina de Flávia Piovesan e Antonio Augusto Cançado Trindade, propôs a equiparação hierárquica dos tratados internacionais de direitos humanos às disposições constitucionais, tendo em vista que possuem a mesma natureza material. Este entendimento, conforme descrito, não foi o que prevaleceu no Plenário, todavia, significa a possibilidade de rediscussão da matéria em prol da efetiva prevalência dos direitos humanos.

\section{Algumas considerações sobre a utilização da tese da supralegalidade pelo STF após o julgamento do recurso extraordinário 466.343-8}

O status hierárquico-normativo atribuído por um Estado aos tratados internacionais de direitos humanos é importante para aferir o comprometimento deste com a ordem internacional em prol dos direitos humanos.

Nesse sentido, apesar de existirem críticas contundentes sobre a tese da supralegalidade adotada pelo STF no julgamento do RE 466.343-1/2008 27 , com as quais comungamos, não se nega que a adoção da mesma representou um avanço para os direitos humanos no Brasil, que até então não diferenciava os tratados de direitos humanos dos tratados internacionais sobre outros temas (salvo se aprovados pelo

27 Dentre as críticas tecidas destaca-se o fato de o Acórdão que adotou a tese da supralegalidade para afastar a prisão civil do depositário infiel ter estendido a vedação a todas as modalidades de depósito, inclusive o depositário judicial, o que foi reforçado com a edição da Súmula Vinculante n. 25. Outro ponto debatido é que esta tese que foi adotada com o intuito de garantir a supremacia da Constituição acabou, na verdade, por enfraquecê-la. Isso porque, a Constituição segue autorizando expressamente a prisão civil do depositário infiel, apesar de estar vedado ao legislador criar qualquer modalidade desta prisão. Ou seja, o legislador está impedido de concretizar o permissivo constitucional expresso o que, na verdade, significa admitir a ausência de aplicabilidade e de eficácia jurídica à Constituição. Neste sentido, conferir SARLET, Ingo Wolfgang. Considerações a respeito das relações entre a Constituição Federal de 1988 e os tratados internacionais de direitos humanos. Espaço Jurídico - Journal of Law [EJJL], v. 12, n. 2, p. 325-344, dez. 2011. Disponível em: <http://editora.unoesc.edu.br/index.php/espacojuridico/ article/view/1328/671>. Acesso em: 21 maio 2013. MALISKA, Marcos Augusto. Constituição e cooperação normativa no plano internacional: reflexões sobre o voto do Ministro Gilmar Mendes no Recurso Extraordinário n. 466.343-1. Espaço Jurídico. Joaçaba, v. 6, p. 113-124, jul./dez. 2008. 
procedimento do $\S 3^{\circ}$ do art. $5^{\circ}$ da $\left.\mathrm{CRFB} / 88\right)$, tratando ambos como se lei ordinária fosse.

Seria melhor para a efetivação dos direitos humanos se o STF tivesse adotado a teoria do status constitucional, realizando uma interpretação sistemática com o $\S 2^{\circ}$ do art. $5^{\circ}$ da Constituição Federal de 1988, conforme defendeu o voto-vista do Ministro Celso de Mello e de acordo com o que preconiza a doutrina renomada sobre o tema (PIOVESAN; MAZZUOLI; TRINDADE).

Todavia, a questão que merece ser discutida é a respeito do efetivo comprometimento do próprio STF com relação à tese adotada.

Como já referido, após a promulgação da Constituição da República de 1988, que ampliou o rol de direitos fundamentais e garantiu maior abertura aos direitos humanos, os compromissos ético-comunitários passaram a ser cobrados de modo incisivo e a jurisdição constitucional teve seu campo de atuação ampliado.

Vislumbra-se que o STF vem aos poucos mudando sua política judicial. Se antes estava sob o paradigma do critério procedimental e uma jurisprudência caracterizada como defensiva (self restraint), atualmente encontra-se agigantado por uma sociedade passiva e paternalista que tudo espera do Estado e que passou a depositar mais confiança no Judiciário do que nos outros Poderes, passando então a adotar uma postura mais substancialista e ativista com utilização de técnicas de interpretação criativas até então desconhecidas no ordenamento jurídico brasileiro, como a própria tese da supralegalidade referida.

Ressalta-se que não é o objetivo deste artigo criticar a adoção de uma posição ativista pelo Supremo, pelo contrário, reconhece-se que, de fato, em um país onde há pouco mais de 20 anos não se garantiam direitos básicos como o de liberdade, a primazia ainda é de proceder a inclusão social afinal existe mais de 16 milhões de pessoas vivendo em extrema pobreza (Dados Censo do IBGE 2010) ao mesmo tempo temse uma Constituição que visa erradicar a miséria e a desigualdade, um Pacto Internacional dos Direitos Civil e Político que em seu preâmbulo reconhece a realização da liberdade do ser humano livre da miséria e 
um Pacto de São José da Costa Rica pelo qual os Estados-membros, dentre eles o Brasil, se comprometem com um desenvolvimento progressivo (art. 26).

O que se almeja apenas é sinalizar para que a postura de efetivação dos direitos humanos e fundamentais pelos Tribunais, em especial, pelo STF, seja constante e racional e que a cada decisão exarada possa representar um avanço para a proteção da pessoa humana, com a consciência de que no processo de decisão/aplicação de uma norma ao caso concreto, o ato de dar um sentido jurídico deve ser atrelado às ideias de sistema constitucional (HESSE, 1991, p. 20) e de sistema internacional de proteção aos direitos humanos, para que arbitrariedades sejam evitadas. (MARRAFON, 2008, p. 118).

Nesse sentido, como o objeto do presente estudo é a análise da jurisprudência do Supremo Tribunal Federal a respeito da posição hierárquico-normativa dos tratados internacionais de direitos humanos, realizou-se uma pesquisa simples de jurisprudência no site do próprio Tribunal (www.stf.jus.br), dos casos julgados posteriormente à decisão do Recurso Extraordinário 466.343-1/SP e que adotaram a referida tese para aplicar uma regra de Direito Internacional de Direitos Humanos presente em um tratado ratificado pelo Brasil em detrimento de uma lei infraconstitucional. Como parâmetro de pesquisa utilizou-se as expressões: "hierarquia tratados internacionais direitos humanos", "tratados supralegal" e "supralegalidade".

Após uma análise de todas as ementas dos julgados detectadas pelo sistema de pesquisa, conforme os parâmetros mencionados, constatou-se que apenas onze ${ }^{28}$ acórdãos utilizaram-se da tese da supralegalidade para aplicar as regras de um tratado internacional de

28 Os julgados são os seguintes: Habeas Corpus n. 96.772/SP, Rel. Min. Celso de Mello, $2^{a}$ Turma, julgado em 09/06/2009; Habeas Corpus n. 90.450/MG, Rel. Min. Celso de Mello, $2^{\text {a }}$ Turma, julgado em 23/09/2008; Habeas Corpus n. 94.695/RS, Rel. Min. Celso de Mello, $2^{\text {a }}$ Turma, julgado em 23/09/2008; Habeas Corpus n. 91.361/SP, Rel. Min. Celso de Mello, $2^{\mathrm{a}}$ Turma, julgado em 23/09/2008; Habeas Corpus n. 90.983/SP, Rel. Min. Celso de Mello, $2^{\text {a }}$ Turma, julgado em 23/09/2009; Habeas Corpus n. 97.256/RS, Rel. Min. Ayres Britto, Tribunal Pleno, julgado em 01/09/2010; Habeas Corpus n. 93.280/SC, Rel. Min. Celso de Mello, $2^{\mathrm{a}}$ Turma, 
direitos humanos em detrimento da legislação infraconstitucional interna, conforme a tese da supralegalidade e dentre os julgados obtidos com a pesquisa, apenas o Habeas Corpus n. 97.256/RS, de relatoria do Ministro Ayres Britto, tratou de questão diversa ao tema da prisão civil do depositário infiel. ${ }^{29}$

A princípio pode se pensar que não houve, a partir de dezembro de 2008, com exceção dos casos referentes à prisão civil do depositário infiel, processos a serem decididos pela Corte que envolvesse o conflito entre regras internas e regras de direito internacional. No entanto, sabendo que o Estado Brasileiro é participante de mais de 20 (vinte) tratados sobre direitos humanos ${ }^{30}$, que protegem a pessoa humana nas suas mais diversas perspectivas, esta conclusão é, no mínimo, ilógica.

julgado em 23/09/2008; Habeas Corpus n. 95.967/MS, Rela. Min ${ }^{\mathrm{a}}$. Ellen Gracie, $2^{\mathrm{a}}$ Turma, julgado em 11/11/2008; Habeas Corpus n. 94.702/GO, Rel ${ }^{a}$. Min ${ }^{a}$. Ellen Gracie, $2^{\mathrm{a}}$ Turma, julgado em 07/10/2008; Habeas Corpus n. 88.240/SP, Rela ${ }^{a}$ Min ${ }^{a}$. Ellen Gracie, $2^{a}$ Turma, julgado em 07/10/2008, Habeas Corpus n. 92.817/RS, Rel. Min. Ricardo Lewandowski, $1^{\text {a }}$ Turma, julgado em 16/12/2008. A íntegra de todos os julgados pode ser consultada no endereço eletrônico do Supremo Tribunal Federal: <www.stf.jus.br>.

29 "EMENTA: HABEAS CORPUS. TRÁFICO DE DROGAS. ART. 44 DA LEI 11.343/2006: IMPOSSIBILIDADE DE CONVERSÃO DA PENA PRIVATIVA DE LIBERDADE EM PENA RESTRITIVA DE DIREITOS. DECLARAÇÃO INCIDENTAL DE INCONSTITUCIONALIDADE. OFENSA À GARANTIA CONSTITUCIONAL DA INDIVIDUALIZAÇÃO DA PENA (INCISO XLVI DO ART. $5^{\circ}$ DA CF/88). ORDEM PARCIALMENTE CONCEDIDA. [...] 4. No plano dos tratados e convenções internacionais, aprovados e promulgados pelo Estado brasileiro, é conferido tratamento diferenciado ao tráfico ilícito de entorpecentes que se caracterize pelo seu menor potencial ofensivo. Tratamento diferenciado, esse, para possibilitar alternativas ao encarceramento. É o caso da Convenção Contra o Tráfico llícito de Entorpecentes e de Substâncias Psicotrópicas, incorporada ao direito interno pelo Decreto 154, de 26 de junho de 1991. Norma supralegal de hierarquia intermediária, portanto, que autoriza cada Estado soberano a adotar norma comum interna que viabilize a aplicação da pena substitutiva (a restritiva de direitos) no aludido crime de tráfico ilícito de entorpecentes". In: BRASIL. Supremo Tribunal Federal. Habeas Corpus n. 97.256. Rel. Min. Ayres Britto, Tribunal Pleno, julgado em 01/09/2010. Disponível em: <www.stf. jus.br>. Acesso em: 20 jan. 2013.

30 Dentre os instrumentos internacionais de proteção aos direitos humanos de maior destaque, pode-se citar: a Declaração Universal de Direitos Humanos (ONU, 1948); o Pacto Internacional dos Direitos Civis e Políticos (ONU, 1966); o Pacto Internacional dos Direitos Econômicos, Sociais e Culturais (ONU, 1966); a Convenção Internacional sobre a Eliminação de Todas as Formas de Discriminação Racial (ONU, 1968); a Convenção Americana de Direitos Humanos (OEA, 1969); a Convenção sobre a Eliminação de Todas as Formas de Discriminação Contra a Mulher (ONU, 1979); a Convenção Contra a Tortura e Outros Tratamentos ou Penas Cruéis, Desumanos ou Degradantes (ONU, 1984); a Convenção Sobre os Direitos das Crianças (ONU, 1989). Para mais informações, consultar: ANNONI, Danielle. O legado da Declaração Universal dos Direitos Humanos das Nações Unidas. Revista lus Gentium. Faculdade Internacional de Curitiba. Curitiba: Ibpex, v. 1, n. 2, p. 81, jul./dez. 2007. 
Tomando como exemplo apenas algumas situações práticas que tiveram maior repercussão se percebe que na verdade houve várias oportunidades para que o Supremo Tribunal Federal aplicasse um tratado internacional de direitos humanos em detrimento da legislação interna, o que, inclusive, se mostrava mais favorável à(s) vítima(s).

Dentre as oportunidades encontra-se a ADPF 153, proposta pelo Conselho Federal da Ordem dos Advogados do Brasil, com o objetivo de que o Supremo Tribunal Federal dessa interpretação conforme a Constituição ao art. $1^{\circ}, \S 1^{\circ}$, da Lei de Anistia (Lei 6.683/1979), de modo a reconhecer que a expressão "crimes conexos" não abrangeria crimes não políticos como torturas, homicídios, desaparecimentos forçados, estupros, lesões corporais e outros delitos praticados por agentes de Estado nos porões da Ditadura Militar.

O Supremo, em abril de 2010, julgou improcedente o referido pedido, ${ }^{31}$ de modo a considerar válida a Lei de Anistia. Isto é, pouco mais de um ano do julgamento do Recurso Extraordinário n. 466.343-8, que reconheceu a prevalência dos tratados internacionais de direitos humanos em face da legislação interna, e mesmo existindo jurisprudência consolidada da Corte Interamericana de Direitos Humanos no sentido de que leis de "auto-anistia" são violadoras do Pacto ${ }^{32}$ (tese apontada pela $\mathrm{OAB})$, não há qualquer menção nos votos vencedores ao referido Pacto e suas disposições. De repente, o Direito Internacional dos Direitos Humanos desapareceu. ${ }^{33}$

31 BRASIL. Supremo Tribunal Federal. ADPF 153. Relator Min. Eros Grau, Tribunal Pleno, julgado em 29/04/2010. Disponível em: <www.stf.jus.br>. Acesso em: 30 mar. 2013.

32 Destaca-se, neste sentido, a decisão proferida, em 24/11/2010, pela Corte Interamericana de Direitos Humanos, no "Caso Julia Gomes Lund e outros" (Caso "Guerrilha do Araguaia"), na qual o Estado brasileiro restou condenado pelos crimes contra a humanidade (mortes, torturas, desaparecimentos), cometidos pelos agentes do Estado, durante a Ditadura Militar brasileira (1964-1985), determinando que estes devam ser devidamente investigados, processados e, conforme o caso, punidos os agentes responsáveis. Esta decisão pode ser visualizada em sua íntegra no seguinte endereço: <http://www.corteidh.or.cr/index.php/jurisprudencia>. Mesmo posicionamento foi adotado pela Corte em relação à Argentina e Chile "Casos Barrios Altos, Almonacid Arellano e Goiburú".

33 Para mais informações acerca do posicionamento da Corte Interamericana de Direitos Humanos vide PIOVESAN, Flávia. Lei de anistia, direito à verdade e à justiça: o Caso Brasileiro. Disponível em: <http://interessenacional.uol.com.br/2012/04/lei-de-anistia-direito-a-verdade-e-ajustica-o-caso-brasileiro/>. Acesso em: 20 mar. 2013. 
Outro exemplo é o que se refere ao direito-garantia a um duplo grau de jurisdição (SARLET, dez. 2011), que em matéria criminal é expressamente assegurado em convenções internacionais ratificadas pelo Estado brasileiro. ${ }^{34}$

Trata-se do caso de modificação de competência para julgamento devido à atração por continência ou conexão do processo do corréu ao foro por prerrogativa de função de um dos denunciados, fato que ocorreu no julgamento da Ação Penal 470, conhecida como "julgamento do mensalão".

De acordo com os argumentos apresentados pela defesa de um dos réus do processo, somente os acusados que detinham prerrogativa de foro prevista na Constituição Federal poderiam ser julgados pelo Supremo, sendo que o processo contra os demais deveria ser encaminhado para a primeira instância, ou seja, para o juiz natural da causa.

Assim, restariam respeitados os direitos assegurados pelo Pacto de San José da Costa Rica, no ponto em que prevê o julgamento pelo juiz natural e o duplo grau de jurisdição.

O Plenário do STF, entretanto, por maioria dos votos $(9 \times 2)$, negou o desmembramento ${ }^{35}$. Dentre os argumentos para a negativa, destacase o voto do Ministro Dias Toffoli que afastou a aplicação do Pacto de San José da Costa Rica ao caso porque, segundo seu entendimento, um pacto internacional a que o Brasil tenha aderido não tem prevalência

34 Neste sentido, conferir o artigo 8, n. 2, h, do Pacto de San José da Costa Rica e artigo 14, n. 5, do Pacto Internacional de Direitos Civis e Políticos.

35 A decisão possui o seguinte teor: "O Tribunal, por maioria, rejeitou a questão de ordem suscitada da tribuna pelo advogado Márcio Thomaz Bastos, ratificada pelos advogados Marcelo Leonardo e Luiz Fernando Sá e Souza Pacheco, de desmembramento do processo, para assentar a competência da Corte quanto ao processo e julgamento dos denunciados que não são detentores de mandato parlamentar, vencidos os Senhores Ministros Ricardo Lewandowski (Revisor) e Marco Aurélio. O Presidente indeferiu a suscitação de questão de ordem pelo advogado Alberto Zacharias Toron, ressalvando que poderá fazê-la por ocasião de sua sustentação oral. Em seguida, após o relatório, ratificado pelo Revisor, o julgamento foi suspenso. Presidência do Senhor Ministro Ayres Britto. Plenário, 02/08/2012". 
sobre a Constituição brasileira ${ }^{36}$ e, havendo conexão, entende que a causa deve ser mantida no STF, até porque existe a Súmula 704 do STF $^{37}$ que prevê a não violação dos princípios constitucionais no caso ${ }^{38}$.

E a tese da supralegalidade? Porque não poderia ser aplicada ao caso a mesma lógica empregada no julgamento da prisão civil do depositário infiel (que também estava prevista na Constituição) de modo a garantir os princípios do duplo grau de jurisdição e o julgamento pelo juiz natural? Constata-se, com isto, que até uma súmula, editada pelo próprio Supremo, prevalece, em tese, sobre um tratado internacional de direitos humanos.

Insta mencionar, ainda, como exemplo, a anomia existente entre o conceito de criança na Convenção sobre os Direitos da Criança e no Estatuto da Criança e do Adolescente - ECA - (Lei 8.069/1990). (GARCIA, 2012). Para o ECA criança é a pessoa com até 12 anos de idade, para a qual se aplica "medida de proteção" no caso da prática de um ato infracional, e adolescente a pessoa maior de 12 anos até 18 anos, para a qual se aplica "medida socioeducativa" na qual se inclui inclusive a possibilidade de privação da liberdade do "menor em conflito com a lei". Já para a Convenção não há o conceito de adolescente, sendo que até os 18 anos a pessoa é considerada criança.

Dessa forma, uma vez que a regra prevista na convenção internacional exara uma maior proteção ao menor e versa sobre direitos humanos, gozando de supralegalidade, pode se chegar à conclusão

36 Conforme notícia disponível em: <http://www.stf.jus.br/portal/cms/verNoticiaDetalhe. asp?idConteudo=213822>. Acesso em: 16 maio 2013.

37 A redação da referida Súmula é a seguinte: "Não viola as garantias do juiz natural, da ampla defesa e do devido processo legal a atração por continência ou conexão do processo do corréu ao foro por prerrogativa de função de um dos denunciados". Disponível em: <http://www.stf.jus. $\mathrm{br} /$ portal/cms/verTexto.asp?servico=jurisprudenciaSumula>. Acesso em: 16 maio 2013.

38 Importante mencionar, todavia, a manifestação do Ministro Celso de Mello, que fez expressa alusão a aplicação do Pacto de San José da Costa Rica, de forma a garantir a aplicação do direito de os réus condenados terem as suas condenações reexaminadas (ainda que pela mesma Corte) (Pacto de San José da Costa Rica, artigo 8, n. 2, alínea h), posicionamento este que tem como base o disposto nos artigos 26 e 27 da Convenção de Viena sobre Direito dos Tratados, 1969 (devidamente ratificada pelo Brasil) e que determina a aplicação do princípio pacta sunt servanda e o próprio primado do direito internacional frente o direito interno. 
de que o conceito de "adolescente" previsto no ECA deveria estar "tacitamente revogado" (GARCIA, 2012).

Entretanto, os juízos de infância e juventude não deixam de aplicar as medidas punitivas ao adolescente previstas no ECA e o STF, mesmo tendo a oportunidade de se manifestar sobre a matéria (HC 111.045/ DF, julgado em 18/12/2012, de relatoria da Ministra Cármen Lúcia e HC 110.250/MS, julgado em 26/06/2012, de relatoria do Ministro Joaquim Barbosa), também nada mencionou sobre o tema.

Diante disso denota-se que a tese da supralegalidade não foi devidamente pensada tanto é que nem o próprio STF cumpre a sua decisão a respeito da hierarquia dos tratados internacionais de direitos humanos o que além de causar grande insegurança aos jurisdicionados e a todo o sistema jurídico brasileiro, prejudica o processo de efetivação dos tratados internacionais de direitos humanos no Brasil.

As circunstâncias apresentadas são apenas alguns exemplos que demonstram que, por enquanto, a interpretação do nível hierárquico dos tratados de direitos humanos realizada pelo STF se mantém reduzida à casuística da prisão do depositário infiel.

Entretanto, se o Supremo Tribunal Federal assumiu para si a função de garantir os direitos humanos e fundamentais, e isso pode ser percebido diariamente na postura ativista das decisões produzidas, deve fazer isso de forma racional, consistente e realmente comprometida com o propósito da força normativa constitucional e sem deixar de considerar o disposto no $\S 2^{\circ}$ do art. $5^{\circ}$ do texto constitucional.

As decisões judiciais não devem fazer sentido apenas no mundo jurídico, mas devem ser parte da realidade concreta da sociedade. A jurisdição constitucional é um dos mecanismos mais eficazes de contenção do poder, no entanto, ela própria deve atuar dentro de limites rígidos (autocontenção), para que não se torne uma instância única e autoritária de poder (governo dos juízes) (HOHMANN, 2007, p.16).

Em um regime democrático, como bem afirma Ronald Dworkin, em seu 'A Virtude Soberana', é preciso fazer uma 
distinção entre preferências pessoais e questões de foro de princípio. O Judiciário pode interferir - e deve - sempre que estiver em jogo uma questão de princípio. Mas não cabe a este poder exarar decisões que manifestem preferências pessoais de seus membros ou de uma parcela da sociedade. Isso por um motivo bastante simples: a democracia é algo muito importante para ficar à mercê do gosto pessoal dos representantes do Poder Judiciário.

Nesse sentido, de que adianta o Supremo decidir que tratados e convenções internacionais de direitos humanos têm status supralegal, se na prática não é conferida tal posição às citadas normas?

A falta de racionalidade e efetividade prática tem um maléfico efeito sobre a crença e confiança no ordenamento jurídico e, talvez, seja o motivo pelo qual o próprio Poder Judiciário, que é visto como a "luz no fim do túnel" para a concretização das promessas da modernidade esteja enfrentando uma verdadeira crise de legitimidade.

Marcelo Neves (2011, p. 1 e 170) trabalha com o conceito de constitucionalização simbólica, como sendo uma alopoiese do sistema jurídico, problema fundamentalmente de países com modernidade periférica, como o caso do Brasil. A teoria analisa justamente a "discrepância entre a função hipertroficamente simbólica e a insuficiente concretização jurídica de diplomas constitucionais".

Neste contexto, em paralelo com a referida tese do simbolismo das normas constitucionais, a questão que surge é se na realidade brasileira não se produzem também "decisões judiciais simbólicas", que aparentemente "acalmam os ânimos de uma sociedade que clama incessantemente por justiça” e, da mesma forma, aparentemente "efetivam os direitos previsto na Constituição Federal e nos Tratados Internacionais de Direitos Humanos".

Da mesma forma, produziriam um efeito simbólico perante a comunidade internacional (MALISKA, 2008, p. 117), permanecendo, entretanto, inalterados os problemas e relações que deveriam ser solucionados, conduzindo apenas a um adiamento retórico da realização 
do modelo constitucional e de proteção aos direitos humanos para um futuro remoto, como se esta fosse possível sem transformações radicais nas relações de poder e na estrutura social. (NEVES, 2011, p. 105).

\section{Conclusão}

Após todas as considerações tecidas a respeito da forma como se deu a abertura do Estado brasileiro à assunção de compromissos internacionais e da maneira como se dá o processo de efetivação das regras assumidas, conclui-se que muito se evoluiu nos últimos anos com relação à proteção dos direitos humanos.

Um dos exemplos dessa evolução foi a mudança de paradigma da jurisprudência do STF, que passou a considerar como inelutável a cooperação entre os Estados nacionais na concretização destes direitos.

Constata-se que, sobretudo, após a ratificação da Convenção de Viena sobre Direito dos Tratados por parte do Brasil, em 1969, o Supremo Tribunal Federal avançou no seu entendimento em garantir a eficácia dos tratados de direitos humanos dentro de nosso ordenamento jurídico interno, de forma a superar os entraves até então existentes sobre a matéria e que isolavam o nosso país da comunidade internacional.

Entretanto, mais do que apontar os avanços alcançados no plano teórico, integrado pelos discursos de abertura e cooperação internacional e pela ratificação de inúmeros tratados internacionais de direitos humanos, o presente artigo analisou de forma crítica os avanços alcançados no plano fático e da realidade social.

Nesse sentido, tendo em vista que o objeto tomado para estudo foi a jurisprudência do STF com relação ao status supralegal dos instrumentos internacionais de que o Brasil é parte, buscou-se analisar o comprometimento da própria Corte constitucional com os avanços por ela mesma proposta.

Após algumas constatações empíricas, conclui-se que a tese do status supralegal dos tratados internacionais de direitos humanos não 
recepcionados nos termos do $\S 3^{\circ}$ do art. $5^{\circ}$ da $\mathrm{CRFB} / 88$, conforme adotada no julgamento do caso do depositário infiel, parece andar meio esquecida pela jurisprudência do Supremo; não se aplicando na prática a outros temas que, apesar de tão importantes quanto à questão do depositário infiel, continuam a ser desprezados em detrimento da legislação interna infraconstitucional contrária, que na maioria das vezes é inclusive menos benéfica às vítimas.

A situação traz o problema da insegurança e da indeterminabilidade do direito, onde, ao que parece, cada caso é julgado de acordo com a conveniência do momento e das circunstâncias e valendo-se de critérios discricionários de interpretação do julgador.

Conforme restou demonstrado no decorrer do artigo, a judicialização é uma circunstância do desenho institucional brasileiro (BARROSO, 2010, p. 40), que exige do Poder Judiciário (especialmente da justiça constitucional) uma postura diferenciada, longe da postura absenteísta, própria do modelo liberal-individualista-normativista. (STRECK, 2011, p. 59).

Todavia, o que não pode ocorrer são decisões políticas e arbitrariedades interpretativas, uma vez que a produção democrática do direito e o papel assumido pelos direitos humanos não pode ficar à mercê de "procedimentos cognoscitivos" ainda reféns do paradigma representacional. (STRECK; BARRETO; OLIVEIRA, 2009).

O Poder Judiciário têm desempenhado importante papel na efetivação dos direitos humanos, porém, discorda-se que seja este o meio exclusivo e mais eficaz para garantir tal propósito.

A adoção de políticas públicas, por exemplo, garante maior generalidade, podendo atingir um maior número de beneficiados. (JUBILUT, 2009, p. 82). Ademais, “o judiciário não pode ser a solução mágica para os problemas dos fracassos e das insuficiências dos demais poderes". (STRECK, 2011, p. 52).

Menciona-se, também, a importante atuação exercida pela Corte Interamericana de Proteção aos Direitos Humanos, cuja jurisdição o 
Brasil aceita como obrigatória e, assim, deve observar e cumprir suas sentenças, que, em última instância, é a real intérprete do Pacto de San José da Costa Rica.

O processo de internacionalização dos direitos humanos depende de cada Estado e do interesse destes em sua promoção.A "era dos direitos" proposta por Norberto Bobbio (1992), da sua conquista e positivação, precisa evoluir para a "era dos deveres", das responsabilidades de todos os atores sociais nacionais e internacionais para com a efetivação dos direitos humanos consagrados internacionalmente há mais de meio século (ANONNI, 2007, p. 85). Enfim, o século XXI cobra mais do que palavras.

\section{Referências}

ANNONI, Danielle. O legado da Declaração Universal dos Direitos Humanos das Nações Unidas. Revista lus Gentium, Curitiba: Ibpex, v. 1, n. 2, p. 81, jul./dez. 2007.

BARROSO, Luís Roberto. No mundo ideal, direito é imune à política, no real, não é bem assim. Disponível em: <http://www.conjur.com. br/2010-fev-16/mundo-ideal-direito-imunepolitica-real-nao-bem-assim>. Acesso em: 27 mar. 2013.

- O direito constitucional e a efetividade de suas normas: limites e possibilidades da constituição brasileira. 7. ed. atual. Rio de Janeiro: Renovar, 2003.

; BARCELLOS, Ana Paula de. O começo da história: a nova interpretação constitucional e o papel dos princípios no direito brasileiro. Interesse Público, Belo Horizonte, v. 5, n. 19, maio 2003. Disponível em: <http://bdjur.stj.jus.br/dspace/handle/2011/32895>. Acesso em: 27 mar. 2013.

BONAVIDES, Paulo. A constituição aberta. Belo Horizonte: Del Rey, 1993. 
CANOTILHO, J. J. Gomes. Direito constitucional e teoria da constituição. 7. ed. Coimbra: Almedina, 2003.

BRASIL. Constituição da República Federativa do Brasil: promulgada em 05 de outubro de 1988. Disponível em: <http://www.planalto.gov.br>. Acesso em: 23 jan. 2013a.

. Emenda Constitucional n. 45: promulgada em 30 de dezembro de 2004. Altera dispositivos dos arts. $5^{\circ}, 36,52,92,93,95,98,99,102$, $103,104,105,107,109,111,112,114,115,125,126,127,128,129$, 134 e 168 da Constituição Federal, e acrescenta os arts. 103-A, 103B, 111-A e 130-A, e dá outras providências. Disponível em: <http://www. planalto.gov.br>. Acesso em: 23 jan. 2013b.

. Decreto-Lei n. 911: promulgado em $1^{\circ}$ de outubro de 1969. Estabelece normas de processo sobre alienação fiduciária e dá outras providências. Disponível em: <http://www.planalto.gov.br>. Acesso em: 23 jan. 2013c.

- Decreto n. 678: promulgado em 06 de novembro de 1992. Promulga a Convenção Americana sobre Direitos Humanos (Pacto de San José da Costa Rica), de 22 de novembro de 1969. Disponível em: <http://www.planalto.gov.br>. Acesso em: 23 jan. 2013d.

. Supremo Tribunal Federal. Súmula n. 704, de 29 de janeiro de 2003. "Não viola as garantias do juiz natural, da ampla defesa e do devido processo legal a atração por continência ou conexão do processo do corréu ao foro por prerrogativa de função de um dos denunciados". Disponível em: <http://www.stf.jus.br>. Acesso em: 24 mar. 2013e

- Supremo Tribunal Federal. Recurso Extraordinário n. 466.343-8, Rel. Min. Cezar Peluso, Tribunal Pleno. Brasília, julgado em 03/12/2008. Disponível em: <www.stf.jus.br>. Acesso em: 20 jan. $2013 f$.

- Supremo Tribunal Federal. ADPF n. 153. Rel. Min. Eros Grau, Tribunal Pleno. Brasília, julgado em 29/04/2010. Disponível em: <www. stf.jus.br>. Acesso em: 30 mar. 2013g. 
. Supremo Tribunal Federal. Habeas Corpus n. 97.256/RS. Rel. Min. Ayres Britto, Tribunal Pleno. Brasília, julgado em 01/09/2010. Disponível em: <www.stf.jus.br>. Acesso em: 13 abr. 2013h.

COELHO, Luiz Fernando. Justiça de transição: in dubio pro humanitante. Revista Bonijuris, Curitiba, v. 24, n. 588, p. 06-19, nov. 2012.

COMPARATO, Fábio Konder. A afirmação histórica dos direitos humanos. 2. ed. rev. e ampl. São Paulo: Saraiva, 2001.

DWORKIN, Ronald. Uma questão de princípio.Tradução Luís Carlos Borges. São Paulo: Martins Fontes, 2001.

GARCIA, Daniel Melo. Consequências e críticas ao status supralegal dos tratados e convenções internacionais sobre direitos humanos não internalizados na forma do art. $5^{\circ}, \S 3^{\circ}$ da Constituição Federal adotado no julgamento do Recurso Extraordinário 466.343/2008. In: ENCONTRO NACIONAL DO CONPEDI, 21., 2012. Uberlândia, Anais eletrônicos... Uberlândia. p. 6517-6553. Disponível em: <http://www.conpedi.org.br/>. Acesso em: 20 dez. 2012.

HABERMAS, Jürgen. Direito e democracia: entre facticidade e validade. Tradução Flavio Beno Siebeneichler. Rio de Janeiro: Tempo Brasileiro, 1997. v. 1.

HESSE, Konrad. A força normativa da constituição. Porto Alegre: Sergio Antonio Fabris, 1991.

HOHMANN, Luiz Henrique Guimarães. Fundamentos da jurisdição constitucional brasileira. Revista Direitos Fundamentais \& Democracia, Curitiba, v. 2, p. 1-20, 2007.

HOMMERDING, Adalberto Narciso. Constituição, Poder Judiciário e Estado Democrático de Direito: a necessidade do debate "procedimentalismo versus substancialismo". Revista do Ministério Público do RS, Porto Alegre, n. 57, jan./abr. 2006. Disponível em: <http://www.amprs.org.br/arquivos/revista_artigo/arquivo_1273603177. pdf>. Acesso em: 04 fev. 2013. 
JUBILUT, Liliana Lyra. A aplicação do direito internacional dos direitos humanos pelo STF. Revista de Direito do Consumidor, São Paulo, n. 72, p. 78-100, out. 2009.

LUDWIG, Celso Luiz. Gadamer: a racionalidade hermenêutica: contraponto à modernidade. In: FONSECA, Ricardo Marcelo (Org.). Crítica da modernidade: diálogos com o Direito. Florianópolis: Boiteux, 2005. p. 145-158.

MALISKA, Marcos Augusto. Constituição e cooperação normativa no plano internacional: reflexões sobre o voto do Ministro Gilmar Mendes no Recurso Extraordinário n. 466.343-1. Espaço Jurídico, Joaçaba, v. 6, p. 113-124, jul./dez. 2008.

MARRAFON, Marco Aurélio. Hermenêutica e sistema constitucional: a decisão judicial entre o sentido da estrutura e a estrutura do sentido. Florianópolis: Habitus, 2008.

MAZZUOLI, Valerio de Oliveira. Curso de direito internacional público. 2. ed. rev. atual. e ampl. São Paulo: Revista dos Tribunais, 2007.

MENDES, Gilmar Ferreira; VALE, André Rufino do. O pensamento de Peter Häberle na jurisprudência do Supremo Tribunal Federal. Disponível em: <http://www.conjur.com.br>. Acesso em: 15 fev. 2013.

MIRANDA, Jorge. Manual de direito constitucional. 3. ed. Coimbra: Coimbra editora, 1996. t. 2.

NEVES, Marcelo. A constitucionalização simbólica. 3. ed. São Paulo: Martins Fontes, 2011.

PIOVESAN, Flávia.Direitos humanos e o direito constitucional internacional. 12. ed. rev., ampl. e atual. São Paulo: Saraiva, 2011.

. Lei de anistia, direito à verdade e à justiça: o caso brasileiro. Disponível em: <http://interessenacional.uol.com.br/2012/04/lei-deanistia-direito-a-verdade-e-a-justica-o-caso-brasileiro/>. Acesso em: 20 mar. 2013.

SARLET, Ingo Wolfgang. A eficácia dos direitos fundamentais. 2. ed. rev. e atual. Porto Alegre: Livraria do Advogado, 2001. 
- Considerações a respeito das relações entre a Constituição Federal de 1988 e os tratados internacionais de direitos humanos. Espaço Jurídico: Journal of Law [EJJL], v. 12, n. 2, p. 325-344, dez. 2011. Disponível em: <http://editora.unoesc.edu.br/index.php/ espacojuridico/article/view/1328/671>. Acesso em: 21 maio 2013.

STRECK, Lenio Luiz. Hermenêutica jurídica $\mathbf{e}(\mathrm{m})$ crise: uma exploração hermenêutica da construção do direito. 10. ed. rev. e ampl. Porto Alegre: Livraria do Advogado, 2011.

- Verdade e consenso: constituição, hermenêutica e teorias discursivas. 4. ed. São Paulo: Saraiva, 2011.

. BARRETTO, Vicente de Paulo; TOMAZ DE OLIVEIRA, Rafael. Ulisses e o canto das sereias: sobre ativismos judiciais e os perigos da instauração de um terceiro turno da constituinte. Revista de Estudos Constitucionais, Hermenêutica e Teoria do Direito (RECHTD), São Leopoldo: Unisinos, v. 1, n. 2, p.75-83, jul./dez. 2009.

TRINDADE, Antônio Augusto Cançado. Tratado de direito internacional dos direitos humanos. 2. ed. rev. e atual. Porto Alegre: Sergio Antonio Fabris, 2003.

- Desafios e conquistas do direito internacional dos direitos humanos no início do século XXI. In: CACHAPUZDE MEDEIROS, Antônio Paulo (Org.). Desafios do direito internacional contemporâneo. Brasília: Funag, 2007. p. 207-322.

. A proteção internacional dos direitos humanos: fundamentos jurídicos e instrumentos básicos. São Paulo: Saraiva, 1991.

Recebido em: 20/06/13

Aprovado em: 24/06/13 